\section{Nuclear enrichment for Japan despite growing worries}

Tokyo

JAPAN Nuclear Fuel Industry Co. began construction on Friday of a uranium enrichment plant in northern Japan that will form part of a huge commercial complex to enrich uranium, reprocess spent nuclear fuel, and store low-level radioactive waste. The complex, which is expected to cost one million million yen ( $\$ 8,000$ million), is intended to reduce Japan's dependence on the US and Europe for nuclear fuel. But construction of the facility is expected to meet strong opposition from the growing anti-nuclear movement in Japan.

The enrichment plant under construction at Rokkasho on the northern tip of the main island of Japan is scheduled to begin operations in 1991. It will initially produce 600 tons SWU (separate work units) of uranium per year and by 2000 this will be increased to 1,500 tons, enough for twelve 1 megawatt reactors or about 30 per cent of Japan's needs.

At present Japan is almost entirely dependent on the US for supplies of enriched uranium and, as a result, reprocessing of Japan's spent fuel is subject to strict US non-proliferation regulations. A reprocessing plant scheduled to open at the Rokkasho site in 1995 will be able to handle a large proportion of Japan's spent nuclear fuel by the turn of the century and this will give Japan greater freedom to handle its nuclear fuel supplies. Vast amounts of spent Japanese nuclear fuel are piled up in reprocessing plants in the UK and France. Shipments of plutonium derived from reprocessing of the fuel are due to begin in the early 1990s and the means of transporting the material has become an issue of great controversy in the US (see right).

Nuclear Fuel Industry Co. has opted to use a conventional centrifugal technique for uranium enrichment at its Rokkasho plant. Laser enrichment techniques are now under development in the US, Japan and Europe and there are fears that the technology at Rokkasho may be outdated by the time it comes into operation.

But competing technology is probably not the biggest of the company's present worries. This year has seen a tremendous surge in growth of the anti-nuclear movement in Japan (Nature 333, 199; 1988). The government and electric power companies have spent millions of dollars over the past few months on public relations campaigns. The Nuclear Safety Commission's latest annual report released last week contains for the first time a question and answer section derived from public hearings to reassure the public of the safety of nuclear power. And on Saturday the first ever drill to practice evacuation of the public was held in the area surrounding a new nuclear power plant in the northern island of Hokkaido.

Chernobyl has slowly awoken urban dwellers to the fact that they may not be immune from the dangers of nuclear accidents at plants located in remote country areas. Takashi Hirose, a writer and anti-nuclear activist, has been particularly influential in cultivating doubts in the minds of the general public. His book entitled Kiken na hanashi (a dangerous
JAPAN has won US approval to transport large quantities of weapons-grade plutonium by sea from Europe despite Congressional and Department of Defense fears that a ship would be a tempting target for a terrorist attack. Only a few kilograms of the plutonium are needed to make a nuclear bomb.

On the one past occasion that Japan carried plutonium from France by sea, the ship was escorted by US, French and Japanese naval vessels and was constantly monitored by satellite. But although the new US-Japan agreement recommends that a military escort be provided, it contains a vaguely-worded proviso that could make an unescorted shipment possible.

Only three months ago the United States and Japan came to a different agreement. The "US-Japan Agreement on Peaceful Use of Nuclear Power" granted Japan 30-year blanket approval to reprocess nuclear fuel of US origin, which is subject to strict US nuclear nonproliferation regulations, provided the plutonium derived from reprocessing in Europe was transported back to Japan by air.

The policy turn-around has angered Congress, largely because of the way it was carried out. Rather than asking that the previous agreement be amended to allow sea transport, giving Congress a 90day review period, the State Department regarded the change as a special case "subsequent arrangement" that would automatically become effective unless Congress took action within fifteen days. The time expired last week and only an exchange of notes is now needed to activate the revised agreement.

The speedy action by the State Department reflects the pressures brought to bear by Japan. According to Alan Kuperman of the Washington-based Nuclear story) is a best seller and he lectures to packed audiences around the country. His message is simple. Minor accidents do happen quite often at Japanese nuclear power plants (although much less frequently than in other countries). No-one can guarantee that a major accident will not occur and as the nuclear industry in Japan rapidly expands the chances of an accident increase.

The complex at Rokkasho has become a focal point of the anti-nuclear campaign. Local groups have collected 600,000 signatures opposing contruction. Five hundred antinuclear demonstrators protested at the remote Rokkasho site on October 9 and further protests are expected.

David Swinbanks
Control Institute, an independent policy study body, the Japanese government was concerned that "a Dukakis administration might not be so compliant" on the issue of plutonium transport by sea and looked for a change in the agreement before the presidential election.

The task of shipping plutonium by air was made more difficult for Japan when Congress specified that casks containing plutonium must be able to withstand a worst-case air accident. An amendment added to a budget bill by Senator Frank Murkowski (Republican, Alaska) succeeded in further recommending that a jumbo jet laden with sample containers should be test crashed.

According to a State Department official the risks of sea transport are "greatly exaggerated" and safety "can easily be assured". Hisashi Dobashi of the Nuclear Safety Bureau of Japan's Science and Technology Agency says the question of whether ships or planes will be used is still "under study". The government is considering building a large patrol boat equipped with a helicopter pad to escort plutonium-carrying ships. But, in the long term, the government's sights are still set on air transport, which is much cheaper. This year's annual report on safety of nuclear energy released by the Nuclear Safety Commission last week concludes that air transport is a "strong candidate" and says that further research and development of crash-proof containers will continue.

Congress has not completely abandoned opposition to sea transport. Both the Foreign Affairs Committee and the Foreign Relations Committee have sent strongly worded notes to President Reagan asking for a new assessment of the risks and raising the possibility that Congress may begin new legislation to "address inadequacies in the treaty".

Alun Anderson and David Swinbanks 